\title{
Anna Dobrowolska
}

Uniwersytet Warszawski

\section{Problem, którego miało nie być. Język milicyjnych dokumentów poświęconych prostytucji w latach 1956-1969}

Zarys treści: Poniższy artykuł jest próbą uzupełnienia wiedzy na temat historii prostytucji w PRL. Służy temu analiza języka stosowanego przez milicjantów do opisu tego zjawiska w latach sześćdziesiątych XX w. Wykorzystane zostały milicyjne rozkazy, sprawozdania i notatki operacyjne, a także artykuły z milicyjnych czasopism („Służba MO”). Język milicyjnych opracowań okazuje się z jednej strony konserwatywny i zakorzeniony w tradycyjnych ramach postrzegania kobiecej seksualności, z drugiej strony jednak można analizować zmianę stosunku do problemu prostytucji wraz z kształtowaniem się dyskursu eksperckiego i profesjonalizacją działań milicyjnych sekcji ds. walki z nierządem.

Słowa kluczowe: historia gender, historia kobiet, prostytucja, płeć kulturowa, Milicja Obywatelska, dyskurs ekspercki

Keywords: gender history, women's history, prostitution, gender, Civic Militia, expert discourse

Prostytucji u nas w kraju nie ma.

Zlikwidowało ja nasze ustawodawstwo.

Paragraf zero, reż. W. Borowik, 1957

„Wprawdzie porządek utrzymujemy, jednak działalność prostytutek jest coraz widoczniejsza” - tak na wyzwania walki z „elementem uciążliwym” skarżyli się warszawscy milicjanci w $1961 \mathrm{r}$. Nie byli w tym osamotnieni - już w połowie lat pięćdziesiątych otwarcie zaczęto mówić o tym, że, wbrew oczekiwaniom, problem prostytucji nie zaniknął po wprowadzeniu w Polsce ustroju komunistycznego. Usuniecie „struktur kapitalistycznego wyzysku” miało w teorii uwolnić kobiety od konieczności zarabiania na życie usługami seksualnymi. Okazało się jednak, że przewidywana zmiana nie nastąpiła, a prostytucja rozwija się szczególnie prężnie w nowych ośrodkach przemysłowych, w których teoretycznie mieszkać miał

\footnotetext{
${ }^{1}$ AKSP, ADM-1475, Notatka informacyjna dot. elementu uciążliwego zam. na terenie m.st. Warszawy, którym są zainteresowane organa MO, 1961, k. 10.
} 
przecież nowy, socjalistyczny człowiek. Wzbudziło to duże zainteresowanie opinii publicznej, a efektem były liczne publikacje w prasie - chociażby słynny reportaż Ryszarda Kapuścińskiego To też jest prawda o Nowej Hucie ze „Sztandaru Młodych" czy film dokumentalny Paragraf zero w reżyserii Włodzimierza Borowika. Choć dyskusje te interpretować możemy częściowo w kategoriach paniki moralnej, to z pewnością wymusiły one na władzy podjęcie określonych działań.

Już na początku $1956 \mathrm{r}$. wydany został oficjalny rozkaz komendanta głównego Milicji Obywatelskiej, w którym wzywano do wzmożenia walki z prostytucjąa ${ }^{2}$. Temat wrócił wtedy na stałe do repertuaru zjawisk, którymi interesowali się funkcjonariusze MO. W latach sześćdziesiątych można obserwować tworzenie się wiedzy milicjantów na temat prostytucji, jej przyczyn i metod walki z nią. Mimo obowiązującego prawa, zakazującego karania czy rejestrowania prostytutek, to właśnie one były głównym przedmiotem uwagi milicjantów. W swoim artykule przyjrzę się więc bliżej językowi, którego Milicja Obywatelska używała do definiowania i opisywania tego zjawiska, a także prześledzę znaczenia, jakie nadawane były poszczególnym pojęciom w toku codziennej pracy operacyjnej. Szczególnie interesować mnie będzie sposób określania przez milicjantów przyczyn prostytucji i tego, kim była według nich prostytutka. Obiektem mojego zainteresowania będzie również kształtowanie się swoistego milicyjnego dyskursu eksperckiego (rozumianego jako ramy mówienia i myślenia o danym problemie społecznym, tworzone przez ekspertów i definiujące granice „normalności” i „dewiacji”). Za pomocą tych narzędzi chciałabym zrekonstruować instytucjonalne rozumienie problemu prostytucji w ramach struktur organizacyjnych Milicji Obywatelskiej.

\section{Od odwilży po „epokę Gierka"}

Lata sześćdziesiąte bywają często nazywane okresem „małej stabilizacji”. Pojęcie to może być jednak mylące przy próbie zastosowania go do opisu rzeczywistości społecznej. Marcin Zaremba twierdzi nawet, że mówić można raczej o „małej destabilizacji” w nastrojach społecznych i poczuciu bezpieczeństwa ${ }^{3}$. Z perspektywy historii społecznej zastrzeżenia te są niezwykle istotne - wydaje się jednak, że jeżeli rozpatrywać będziemy historię Milicji Obywatelskiej jako dzieje instytucji, pojęcie „małej stabilizacji” może znaleźć swoje zastosowanie. Przemawiają za tym różnorodne argumenty. Po pierwsze, jest to czas umacniania się tego organu władzy. Po burzliwych latach tużpowojennych i późniejszych związkach z Urzędem Bezpieczeństwa w latach stalinizmu, w 1956 r. Milicja Obywatelska

${ }^{2}$ GAP, 4/59, Rozkaz Komendanta Głównego Milicji Obywatelskiej z dn. 23 I 1956 nr 2/56 w sprawie wzmożenia walki z prostytucją, k. 20-25.

${ }^{3}$ Por. M. Zaremba, Społeczeństwo polskie lat sześćdziesiątych - miedzy „małą stabilizacja” a „mała destabilizacją", w: Oblicza Marca 1968, red. K. Rokicki, S. Stępień, Warszawa 2004, s. 24-51. 
zyskała przynajmniej częściową niezależność i możliwości rozwoju jako formacja policyjna ${ }^{4}$. Lata sześćdziesiąte to zatem okres instytucjonalnej stabilizacji i kształtowania się struktur operacyjnych, umożliwiających sprawniejszą walkę z przestępczością. Po drugie, widać wtedy początek stabilizacji personalnej ze względu na rozpoczęcie służby przez nowe kadry, ludzi wyszkolonych i profesjonalnie przygotowanych do pracy $w$ formacji policyjnej ${ }^{5}$.

Ramy chronologiczne moich badań wynikają jednak nie tylko z zastosowania koncepcji „małej stabilizacji” do historii instytucjonalnych przemian w MO. Ograniczam się do lat sześćdziesiątych również dlatego, że był to czas głębokich zmian $\mathrm{w}$ metodach przeciwdziałania prostytucji. Cezurą początkową jest rok 1956 - wtedy, na fali odwilży, obiektem zainteresowania opinii publicznej stają się różnorodne problemy społeczne, dotychczas przemilczane jako niepasujące do propagandowego obrazu socjalistycznego państwa. W tym czasie w prasie przetoczyła się dyskusja na temat tego zjawiska, jego przyczyn i metod przeciwdziałania ${ }^{6}$. Na mocy rozkazu $\mathrm{nr} 2 / 56 \mathrm{w}$ sprawie wzmożenia walki z prostytucją w komendach miejskich $\mathrm{MO}$ zaczęły być tworzone sekcje ds. walki z nierządem ${ }^{7}$. Lata sześćdziesiąte to czas ich rozwoju i wypracowywania metod działania. Z kolei drugą klarowną cezurą, oznaczającą koniec pewnej epoki w historii PRL-owskiej prostytucji, jest początek lat siedemdziesiątych i przejęcie władzy przez Edwarda Gierka. Poprawa jakości życia (w stosunku do poprzedniego okresu), a także otwarcie kraju na świat i związany z tym wzrost liczby cudzoziemców odwiedzających Polskę (głównie Warszawę i inne duże miasta), oznaczały także zmianę charakteru prostytucji i idącą za tym konieczność redefinicji pewnych pojęć. Nowa epoka przyniosła również potrzebę zmiany metod działania i świadomości samych milicjantów. Ze względu na te aspekty, na potrzeby badania zdecydowałam się wydzielić lata 1956-1969 jako oddzielny etap w historii prostytucji.

\section{Ani kobiety, ani pracownice - kilka słów o stanie badań}

Choć prostytucja jest zjawiskiem obecnym właściwie w każdej epoce i kulturze, nie stanowiła dotychczas obiektu masowego zainteresowania historyków, szczególnie jeżeli chodzi o historiografię polską. Wyjątkiem są prace Jolanty

\footnotetext{
${ }^{4}$ P. Majer, Milicja Obywatelska w systemie organów władzy PRL. Zarys problematyki i źródła, Toruń 2003, s. 64-65.

${ }^{5}$ J. Eisler, Milicja Obywatelska w latach 1945-1989, w: Historia i rola społeczna formacji policyjnych w jubileuszu 85-lecia, red. G. Gryz, G. Jach, M. Laurentowska, Legionowo 2005, s. 110-111.

${ }^{6}$ J. Kochanowski, Rewolucja międzypaździernikowa. Polska 1956-1957, Kraków 2017, s. 45-61.

${ }^{7}$ GAP, 4/59, Rozkaz Komendanta Głównego Milicji Obywatelskiej z dn. 23 I 1956 nr 2/56 w sprawie wzmożenia walki z prostytucją, k. 21.
} 
Sikorskiej-Kuleszy, poświęcone XIX stuleciü, a także badania nad prostytucją i marginesem społecznym $\mathrm{w}$ dwudziestoleciu międzywojennym, które prowadzi Mateusz Rodak ${ }^{9}$. W tym miejscu warto wspomnieć również badania Keely Stauter-Halsted, zajmującej się okresem zaborów ${ }^{10}$, a także Maren Röger, która $\mathrm{z}$ kolei badała prostytucję w czasie II wojny światowej ${ }^{11}$.

Jeżeli chodzi o badania nad PRL-em, temat prostytucji poruszali Barbara Klich-Kluczewska i Krzysztof Kosiński ${ }^{12}$. Ze względu na różną podstawę źródłową autorzy dochodzą jednak do różnych wniosków. Kosiński zainteresowany był związkami prostytucji z patologiami społecznymi (przede wszystkim pijaństwem). Klich-Kluczewska z kolei starała się umieścić źródła na temat prostytucji w szerszym kontekście polityki płci PRL. Analizy te nie wyszły jednak poza krótkie artykuły i jeden rozdział w książce. Problem wymaga więc zdecydowanie dalszego, systematycznego opracowania. Warte zauważenia jest również to, że temat prostytucji nieobecny jest w książkach czy pracach zbiorowych, co do których zupełnie uprawnione jest oczekiwanie, że się do niego odniosą. Mam na myśli po pierwsze opracowania poświęcone historii kobiet $\mathrm{w} \mathrm{PRL}^{13}$, ale przede wszystkim artykuły podejmujące temat kobiecej pracy ${ }^{14}$. Poza opisanymi wyżej wyjątkami, prostytutki nie istnieją w świadomości większości historyków ani jako kobiety, ani jako pracownice.

Niedostatek historycznych opracowań rekompensować mogą socjologiczne badania $\mathrm{z}$ epoki. Temat prostytucji był przez cały PRL przedmiotem refleksji socjologicznej i seksuologicznej ${ }^{15}$. Magdalena Jasińska w latach pięćdziesiątych

${ }^{8}$ J. Sikorska-Kulesza, Zło tolerowane. Prostytucja $w$ Królestwie Polskim w XIX wieku, Warszawa 2004. O prostytucji w epoce nowożytnej por. np. A. Karpiński, Kobieta w mieście polskim w drugiej połowie XVI i w XVII wieku, Warszawa 1995.

${ }^{9}$ M. Rodak, Prostytutki żydowskie w województwie lubelskim $w$ dwudziestoleciu międzywojennym. Analiza środowiskowa, „Kwartalnik Historii Żydów” 2006, nr 3, s. 379-390; idem, Prostytucja w Lublinie w latach 1918-1939, w: Metamorfozy społeczne, red. J. Żarnowski, t. 2, Warszawa 2007, s. $189-212$.

${ }^{10}$ K. Stauter-Halsted, The devil'schain. Prostitution and social control in partitioned Poland, Ithaca 2015.

${ }^{11}$ M. Röger, Kriegsbeziehungen. Intimität, Gewalt und Prostitution im besetzten Polen 1939-1945, Frankfurt 2015.

${ }^{12}$ B. Klich-Kluczewska, Unzüchtiger Realsozialismus. Prostitution in der Volksrepublik Polen, „Osteuropa. Mythos Europa. Prostitution, Migration, Frauenhandel” 6, 2006, s. 303-317; K. Kosiński, Prostytucja w PRL, „Polska 1944/45-1989” 9, 2009, s. 85-132; idem, Historia pijaństwa w czasach PRL. Polityka - obyczaje - szara strefa - patologie, Warszawa 2008, s. 592-610. Por. też B. Brzostek, Za progiem. Codzienność w przestrzeni publicznej Warszawy lat 1950-1970. Warszawa 2007, s. 427-434, 488-494; J. Kochanowski, op. cit.

${ }^{13}$ Kobiety „na zakręcie”: 1933-1989, red. E. Chabros, A. Klarman, Wrocław 2014. Por. Dzieje kobiet $w$ Polsce, red. K. Makowski, Poznań 2014.

${ }^{14}$ Por. Kobieta i praca, red. A. Żarnowska, A. Szwarc, Warszawa 2000.

${ }^{15} \mathrm{~W}$ dwudziestoleciu międzywojennym również powstawały naukowe opracowania poświęcone tej tematyce, por. I. Surmacka, Czynniki prostytucji oraz charakterystyka prostytutek. Ankieta zebrana wśród prostytutek warszawskich, Warszawa 1939. 
prowadziła wywiady z młodymi prostytutkami z Warszawy ${ }^{16}$. Swoje badania powtarzała w późniejszych latach, co nadaje im dużą wartość porównawczą ${ }^{17}$. Podobne badania w latach siedemdziesiątych przeprowadzili Michał Antoniszyn i Andrzej Marek, ale obejmowały one obszar Trójmiasta i Włocławka ${ }^{18}$. W pracach tych znajdziemy dużo informacji na temat pochodzenia społecznego, wykształcenia czy wyuczonego zawodu kobiet zajmujących się prostytucją. Badacze starali się odpowiedzieć na pytanie o przyczyny rozpoczynania przez młode kobiety pracy prostytutki ${ }^{19}$. Choć oczywiście wpływ na uzyskane wyniki miała przyjęta metodologia i okoliczności prowadzenia badań (np. współpraca z Milicją Obywatelską), zebrane $\mathrm{w}$ tych opracowaniach informacje są bezcenne dla nakreślenia całościowego obrazu zjawiska. Z kolei badania seksuologiczne zajmowały się inną stroną problemu - po pierwsze związkiem prostytucji z przestępczością i patologiami społecznymi, a po drugie kategorią normalności w stosunkach płciowych ${ }^{20}$. Badania seksuologów, obok analiz milicyjnych i kryminologicznych, stanowią ważną część dyskursu eksperckiego na temat prostytucji. Powinny być też rozpatrywane na tle innych opracowań seksuologicznych, jako część szerszej debaty na temat seksualności i ról płciowych ${ }^{21}$.

\section{Źródła}

Na brak historycznych opracowań dotyczących prostytucji wpływ ma oczywiście niedostatek źródeł. Jako zjawisko nielegalne lub półlegalne, zawsze funkcjonowała na marginesie życia społecznego, co oczywiście skutkowało stosunkowo nielicznymi śladami w źródłach. Same prostytutki, w większości kobiety słabo wykształcone, pochodzące z niższych klas społecznych, nie wytwarzały również własnych źródeł, które przetrwałyby do naszych czasów. Nie jest to także zjawisko, które można by łatwo zbadać za pomocą wywiadów historii mówionej ze względu na trudność dotarcia do świadków. Wszystkie te zastrzeżenia nie oznaczają jednak, że prostytucja jest zjawiskiem niepoddającym się historycznemu opisowi. Źródeł

${ }^{16}$ M. Jasińska, Proces społecznego wykolejenia młodocianych dziewcząt, Warszawa 1967.

${ }^{17}$ M. Jasińska, Problematyka prostytucji w Polsce, w: Zagadnienia patologii społecznej, red. A. Podgórecki, Warszawa 1976, s. 435-456; eadem, Prostytucja młodocianych $w$ Warszawie na przełomie lat siedemdziesiątych i osiemdziesiątych, „Archiwum Kryminologii” 12, 1985, s. $129-137$.

${ }^{18}$ M. Antoniszyn, A. Marek, Prostytucja w świetle badań kryminologicznych, Warszawa 1985.

${ }^{19}$ Por. I. Ślęzak, Kolektywny wymiar budowania zaangażowania w pracę seksualną kobiet świadczacych ustugi seksualne $w$ agencjach towarzyskich, „Przegląd Socjologii Jakościowej” 10, 2014, nr 4, s. 56-79.

${ }^{20}$ Por. np. Problemy seksuologii, t. 2, red. T. Bilinkiewicz, Warszawa 1965.

${ }^{21}$ Por. A. Kościańska, Płeć, przyjemność i przemoc. Kształtowanie wiedzy eksperckiej o seksualności $w$ Polsce, Warszawa 2014. 
jest wiele, są jednak bardzo rozproszone i różnorodne, co wymaga od badaczy i badaczek dużej skrupulatności i uwagi ${ }^{22}$.

Temat prostytucji z pewnością wymaga dokładnej kwerendy. W tym artykule skupię się jednak wyłącznie na analizie dokumentów milicyjnych dotyczących tej tematyki. Znajdziemy tam zarówno dyskurs ekspercki (czasopismo „Służba MO”), jak i oficjalne zarządzenia regulujące pracę milicjantów, a także realia funkcjonowania konkretnych jednostek (np. roczne sprawozdania Sekcji do walki z Nierządem Karalnym przy Wydziale Kryminalnym Komendy Stołecznej MO). Choć oczywiście jest to źródło jednostronne, pozwalające opisywać sytuację wyłącznie z perspektywy milicyjnej, podejmuje jednak wiele ciekawych tematów. Dokumenty, na których oprę swoje badania, pochodzą z Głównego Archiwum Policji i Archiwum Komendy Stołecznej Policji ${ }^{23}$. Nie jest to oczywiście kompletna czy reprezentatywna próba, jeżeli chodzi o działalność Milicji Obywatelskiej w walce z prostytucją. Dosyć dobrze odpowiada ona jednak zakreślonym przeze mnie ramom badawczym - na jej podstawie analizować można język stosowany przez MO do opisu problemu prostytucji, jego definiowania, a także opisać podejmowane (przynajmniej w sferze deklaratywnej) działania. Po przeanalizowaniu zbioru dokumentów z lat sześćdziesiątych doszłam do wniosku, że można mówić o zjawisku nasycenia teoretycznego ${ }^{24}$, które daje mi prawo wyciągać wnioski na podstawie tego źródła.

Wyzwania związane $\mathrm{z}$ wykorzystaniem określonego typu źródeł będę omawiać na konkretnych przykładach. Po pierwsze, wykorzystywać będę wspomniane już wcześniej artykuły z milicyjnych czasopism. Ich autorami byli milicjanci: Jan Bielecki, Kazimierz Matysiak i Stanisław Górnicki. Prace te były wynikiem profesjonalnych badań kryminologicznych (np. Górnicki napisał pracę magisterską na temat prostytucji ${ }^{25}$ ). Prezentują one dyskurs ekspercki, a ich autorzy to oficerowie $\mathrm{MO}$, posiadający często stopnie naukowe, a także doświadczenie w pracy operacyjnej i dostęp do wewnętrznych statystyk i raportów. Do opisu

\footnotetext{
22 Przykładowe źródła, które możemy wykorzystać do badania prostytucji po 1945 r., to np. dokumenty pochodzenia milicyjnego, dokumenty partyjne, a także archiwa instytucji: np. Służby Bezpieczeństwa, Naczelnej Izby Kontroli, Komisji do Walki ze Szkodnictwem Gospodarczym i Nadużyciami, Ministerstwa Spraw Wewnętrznych i Ministerstwa Zdrowia i Opieki Społecznej. Ważne są również dokumenty wyprodukowane przez organizacje quasi-społeczne, np. Ligę Kobiet czy Towarzystwo Świadomego Macierzyństwa. Tę bazę źródłową uzupełniają wspomniane już wcześniej badania socjologiczne z epoki. Ważnym kontekstem dla analizowania zjawiska powinna być również kultura popularna (filmy, seriale), literatura piękna, reportaże czy prasa.

${ }^{23}$ Kwerenda na temat prostytucji została przeprowadzona w Głównym Archiwum Policji w 2007 r. na zlecenie dr. hab. Marcina Zaremby. Za udostępnienie materiałów na potrzeby mojego artykułu serdecznie dziękuję.

${ }^{24}$ Pojęcia "nasycenie teoretyczne” używam za Krzysztofem Koneckim (por. K. Konecki, Studia $z$ metodologii badań jakościowych, Teoria ugruntowana, Warszawa 2010).

25 Por. S. Górnicki, Prostytucja a przestępczość, cz. 1, „Służba MO” 1963, nr 1 (34), s. 21.
} 
zjawisk używają oni języka naukowego. Ich celem jest charakteryzowanie zjawiska, analiza jego przyczyn i podanie rekomendacji na przyszłość. W związku z tym mogą pozwolić sobie na głosy krytyczne wobec postawy innych milicjantów. Ich doświadczenie jest jednak prawdopodobnie zupełnie odmienne od codziennej pracy szeregowych funkcjonariuszy i nie należy nakładać na siebie tych perspektyw. Po drugie, podstawą źródłową mojego artykułu będą oficjalne rozkazy milicyjne, przede wszystkim pochodzące z Komendy Głównej MO. Określają instytucjonalne ramy działania, definiują najważniejsze problemy, z którymi zmierzyć się mają funkcjonariusze, a także zalecają określone rozwiązania operacyjne. Rozkazy charakteryzują się lakonicznym, oficjalnym językiem. Znajdziemy w nich również ideologiczne hasła - $\mathrm{np}$. fragmenty o walce $\mathrm{z}$ reliktami burżuazyjnego ustroju. Jeżeli chodzi o zastosowanie tego typu dokumentów, to służyć one mogą diagnozie głównych problemów, na które musieli reagować milicjanci, a także analizie ram prawno-organizacyjnych, w których funkcjonowali. Trudno jednak doszukiwać się w nich realiów działania poszczególnych jednostek, o których Komenda Główna najprawdopodobniej niewiele wiedziała. Trzecim typem omawianych przeze mnie źródeł będą sprawozdania i notatki dotyczące pracy poszczególnych jednostek MO. Mogą one dostarczyć wiedzy o tym, w jaki sposób poszczególne zarządzenia były wprowadzane w życie, a także jaka była specyfika regionalna i różnice między poszczególnymi częściami kraju. Warto jednak pamiętać, że przy pisaniu sprawozdań zawsze istnieje tendencja do powiększania swoich zasług i umniejszania niedociągnięć, dlatego dokumenty te również należy traktować krytycznie.

\section{Badanie prostytucji - dylematy metodologiczne}

Badacze i badaczki podejmujący problem prostytucji powinni być świadomi trudności metodologicznych i etycznych, na jakie mogą natrafić. Problemem, który zawsze towarzyszy historykowi w badaniach archiwalnych, jest pytanie o język źródeł. W przypadku archiwów Milicji Obywatelskiej, instytucji państwa o cechach totalitarnych i autorytarnych, z pewnością powinniśmy zachować wzmożoną czujność. Jednak istnieje również drugi problem związany z analizą dokumentów milicyjnych, który szczególnie silnie widać w przypadku prostytucji. Język, jakiego używali funkcjonariusze do opisu zjawisk, z którymi się stykali, nie jest neutralny. Proponowane przez funkcjonariuszy diagnozy i definicje są głęboko osadzone w porządku genderowym i społecznym. Definiowanie prostytucji jako dewiacji wynika $\mathrm{z}$ określonego paradygmatu postrzegania kobiecej seksualności. Badacze i badaczki, zajmujący się taką tematyką, powinni być świadomi tych uwikłań i wykorzystywać źródła do ich krytycznej interpretacji. 
Zajmując się tematami trudnymi, a do takich należy prostytucja, badacze i badaczki powinni być świadomi również własnych postaw wobec badanego zjawiska. Łączy się z tym problem piętna w badaniach, o którym pisała Izabela Ślęzak ${ }^{26}$. Zauważyła ona, że istnieją pewne stereotypy i skojarzenia, które rządzą społecznym postrzeganiem prostytucji. Piętno ma również wpływ na relacje badającego $\mathrm{z}$ badanymi (prostytutkami). W przypadku mojej pracy nie zachodzi bezpośredni kontakt $\mathrm{z}$ analizowaną grupą - ani $\mathrm{z}$ milicjantami, ani z prostytutkami - uważam jednak, że pytanie o uprzedzenia jest ważne również dla mnie. Po pierwsze, dotyczy ono źródeł, na których pracuję. Jak już wspominałam, świadomość języka i społecznych uwarunkowań, w których powstawały źródła, jest niezwykle ważna przy interpretowaniu wyników badania. Po drugie, konieczna jest również autorefleksja nad postawą badacza/badaczki wobec zjawiska prostytucji. Podczas analizy treści, którą przeprowadziłam, starałam się zachować dystans do tematu. Przejawiało się to w używaniu neutralnego słownictwa, a także stosowaniu wyraźnych cudzysłowów i cytatów, kiedy przywoływałam treść źródeł. Mam nadzieję, że udało mi się uniknąć oceniania wyborów życiowych kobiet, które w latach sześćdziesiątych zajmowały się prostytucją.

\section{"Nawyki moralności burżuazyjnej"27. O poszukiwaniu definicji}

Podczas pobieżnej lektury milicyjnych dokumentów związanych z tematem prostytucji można odnieść wrażenie, że największym przeciwnikiem funkcjonariuszy MO były same prostytutki. Zarówno w analizach statystycznych, jak i w sprawozdaniach z działań operacyjnych czy tekstach szkoleniowych nacisk kładziono na odpowiednie rozpoznanie prostytutek, to przeciwko nim kierowano też wiele opisywanych w dokumentach działań (np. kontrole, ewidencje). Tymczasem analiza stanu prawnego zmusza do zauważenia, że samo uprawianie prostytucji nie było w PRL-u nielegalne. Wręcz przeciwnie - w 1952 r. Polska ratyfikowała abolicjonistyczną konwencję ONZ, w której zobowiązywano się do zaprzestania karania i jakiejkolwiek kontroli prostytutek. Od tego czasu organy MO nie powinny były prowadzić nawet rejestrów prostytutek, związanych z osławionymi „czarnymi książeczkami” i systemem reglamentacyjnym. Także obowiązujący kodeks karny, czyli Kodeks Makarewicza z 1932 r., który posiadał cały rozdział

\footnotetext{
${ }^{26}$ I. Ślęzak, Refleksje nad zagadnieniem piętna $w$ relacjach badacza i badanych na podstawie wywiadów z kobietami świadczącymi ustugi seksualne, „Nauka i Szkolnictwo Wyższe” 2013, nr 1/41, s. $149-162$.

27 Sformułowanie „nawyki moralności burżuazyjnej” pochodzi z rozkazu KGMO z 1956 r. Por. GAP 4/59, Rozkaz Komendanta Głównego Milicji Obywatelskiej z dn. 23 I 1956 nr 2/56 w sprawie wzmożenia walki z prostytucją, k. 20-25.
} 
poświęcony przestępstwom związanym z nierządem, nie karał za samo uprawianie prostytucji. Wyjątkiem była tu prostytucja homoseksualna, której karalność zniesiono dopiero w nowym kodeksie z $1969 \mathrm{r}^{28}$ Analiza milicyjnych dokumentów zmusza jednak do refleksji nad realnym stosowaniem tego prawa. Kluczem do opisania milicyjnego dyskursu wokół problemu prostytucji powinno być więc zdefiniowanie, kim tak naprawdę jest prostytutka oraz dlaczego jej działalność ma stanowić obiekt zainteresowania i kontroli.

\section{Kim jest prostytutka?}

Jednym z głównych problemów, na które zwracali uwagę milicjanci piszący o prostytucji, był brak jasnej definicji zjawiska. W dużej część opracowań znajdujących się w Archiwum Głównym Policji znajdziemy obszerne fragmenty, w których autorzy starają się stworzyć jasną definicję prostytucji, odwołując się często do własnych doświadczeń z pracy operacyjnej. $\mathrm{W}$ archiwalnych materiałach widać również ścieranie się ze sobą różnych koncepcji postrzegania tego zjawiska. O ile co do wskazania cech, które sprawiają, że dany proceder nazwać można prostytucją, milicjanci są dosyć zgodni, to różnią się znacząco w ocenie moralnej zjawiska i w sposobach jego interpretowania.

Warto zaznaczyć, że definicja prostytucji nie pojawia się w rozkazach i wytycznych dotyczących walki $z$ nierządem karalnym ${ }^{29}$. Prawdopodobnie wynika to z nieobecności tego paragrafu w kodeksie karnym, którego przepisy wyznaczały ramy funkcjonowania milicji. Trudno jednak ścigać przestępstwa powiązane z prostytucją (jak sutenerstwo czy kuplerstwo), gdy nie ma jasności co do cech tego zjawiska. Dlatego większość definicji podawanych w milicyjnych opracowaniach ma charakter użytkowy - wskazuje na poszczególne cechy, na podstawie których można stwierdzić, że dane zachowanie jest prostytucją. Autorzy powołują się też na doświadczenia organów milicji ${ }^{30}$. Przykładem może być definicja podana przez Kazimierza Matysiaka: „Za cechy indywidualne prostytucji uznano względną bezwyborowość partnerów, gotowość prostytutki do oddania swojego ciała do dyspozycji partnera i odpłatność materialną"31. Stanisław Górnicki dodaje do jeszcze dwie cechy: „mnogość partnerów” i „obojętność uczuć”.

\footnotetext{
${ }^{28}$ Art 207 k.k. z 1932 r.

${ }^{29}$ Por. GAP, 74x/4, Rozkaz nr 3/59 z dn. 6 II 1959 - Wytyczne ws. ścigania przestępstw nierządu karalnego, przeciwdziałania prostytucji oraz współudziału organów MO w zwalczaniu chorób wenerycznych.

${ }^{30}$ S. Górnicki, Prostytucja a przestępczość, cz. 1, „Służba MO” 1963, nr 1 (34), s. 23.

${ }^{31}$ K. Matysiak, Przestęstwa eksploatacji prostytucji i jej sprawcy na terenie Trójmiasta, „Służba MO” 1969 , nr 3 (72), s. 342.
} 
Jednak definicje nie skupiają się wyłącznie na określaniu cech osób zajmujących się prostytucją. Obiektem zainteresowania milicjantów była również prostytucja jako zjawisko społeczne. Powtarzającym się motywem jest traktowanie prostytucji jako zjawiska ściśle związanego ze „społeczeństwami rządzonymi przez zorganizowany ucisk (społeczeństwa stanowe i klasowe)"32. W rozkazie komendanta głównego MO ws. wzmożenia walki z prostytucją z 1956 r. czytamy: „Zjawisko prostytucji w naszych warunkach jest pozostałością ustroju kapitalistycznego oraz wypływa z zakorzenionych w społeczeństwie nawyków moralności burżuazyjnej. Likwidując właściwe ustrojowi kapitalistycznemu stosunki ekonomiczno-społeczne władza ludowa usuwa źródła demoralizacji i podstawy, na których rozwija się prostytucja" ${ }^{33}$. Warto zwrócić tutaj uwagę na dwa aspekty. Po pierwsze, walka z prostytucją została umieszczona przez milicjantów na odcinku walki ideologicznej. Nie jest traktowana jako zwykłe przestępstwo, ale jako zjawisko obce socjalistycznej moralności. Seksualność, a w tym prostytucja, nie jest sprawą prywatną obywateli, ale elementem państwowej polityki. Wpisuje się to $\mathrm{w}$ inne tendencje związane z kontrolą państwa nad kobiecym ciałem, np. z zakazem aborcji w okresie stalinizmu i późniejszą liberalizacją ustawy. Druga kwestia, na którą warto zwrócić uwagę, to pewna "postępowość” w sposobie traktowania prostytucji przez Milicję Obywatelską. Mówienie o zjawisku społecznym i próby szukania jego przyczyn w mechanizmach wyzysku i wykluczenia oznaczają odejście od, popularnego szczególnie na początku XX w., stygmatyzowania samych prostytutek $^{34}$. Kobiety zajmujące się prostytucją nie są w tej optyce traktowane jako dewiantki, z góry skazane na życie na marginesie społeczeństwa i same odpowiedzialne za swoją sytuację życiową. Trudno powiedzieć, jakie przełożenie miały te teorie na praktykę codziennej pracy milicyjnych jednostek. Prawdopodobnie postawa zwykłych milicjantów wobec prostytutek daleka była jednak od wyrozumiałości i idei abolicjonistycznych.

Mówienie o głębokim zakorzenieniu zjawiska prostytucji w ustroju kapitalistycznym jest oczywiście zgodne z prezentowaną przez władze PRL-u propagandową wizją, w której czasy rządów sanacyjnych czy „zgniły Zachód” były synonimami wyzysku i moralnego upadku. Wydaje się jednak, że, przy okazji, proponowana przez milicjantów interpretacja przyczyn istnienia zjawiska prostytucji jest mniej opresyjna w stosunku do samych prostytutek, a także umożliwia lepsze zrozumienie ich sytuacji. Wpływ na takie stanowisko mogła też mieć konwencja abolicjonistyczna, która wymusiła na organach ścigana większe skupienie na przestępstwach towarzyszących prostytucji, a co za tym idzie refleksję nad jej społecznymi uwarunkowaniami.

32 Por. S. Górnicki, op. cit., cz. 1, s. 22-23.

${ }_{33}$ GAP, 4/59, Rozkaz Komendanta Głównego Milicji Obywatelskiej z dn. 23 I 1956 nr 2/56 w sprawie wzmożenia walki z prostytucją, k. 20-25.

${ }^{34}$ J. Sikorska-Kulesza, op. cit. 


\section{Przyczyny prostytucji}

Problemy związane ze zdefiniowaniem, czym naprawdę jest prostytucja, wynikały poniekąd z braku znajomości przyczyn tego zjawiska. Hasła o kapitalistycznym wyzysku pasowały do rozkazów i oficjalnych przemówień, jednak codzienna praca operacyjna wymagała zastanowienia, czemu w społeczeństwie socjalistycznym prostytucja dalej istnieje, a nawet ma się coraz lepiej. Jak zauważa Stanisław Górnicki, „nieuwzględnienie tych elementów w pierwszych latach po wyzwoleniu, doprowadziło do błędnych teorii, zakładających, że sama zmiana ustroju likwiduje przyczyny powstawania ujemnych zjawisko społecznych związanych z ustrojem klasowym (prostytucja, przestępstwa). Zapomniano o tym, że likwidacja tych ujemnych zjawisk wymaga przekształcenia świadomości społecznej i stworzenia odpowiednich warunków do realizacji słusznych założeń ustrojowych. Zmianie każdego bowiem ustroju towarzyszy dłuższy lub krótszy okres przejściowy, w którym na równi z nowym rządzą jeszcze stare zasady i przyzwyczajenia”35.

Zintensyfikowane działania milicyjnych sekcji ds. walki z nierządem pozwoliły funkcjonariuszom na określenie kilku podstawowych przyczyn zjawiska prostytucji. Wśród najczęściej wspominanych w dokumentach i opracowaniach możemy wyróżnić ciężkie warunki materialne. Milicjanci łączyli je przede wszystkim z powojenną sytuacją, kiedy wiele kobiet zostało przez okoliczności zmuszonych do zarabiania na życie i utrzymywania rodziny, a nie znajdowały innej wystarczająco dobrze płatnej pracy. Drugim często wymienianym powodem rozpoczęcia pracy w charakterze prostytutki był brak przygotowania do życia, objawiający się niskim wykształceniem czy nieposiadaniem wyuczonego zawodu. Dodatkowym obciążeniem wielu prostytutek była konieczność utrzymania dzieci lub rodziców ${ }^{36}$.

Ważnym aspektem, na którym skupiali się niektórzy milicjanci, była kwestia odpowiedniego wychowania. Wiązali oni problem prostytucji z niewłaściwymi wzorcami wyniesionymi z domu, a także $\mathrm{z}$ "rozwiązłym trybem życia” i zbytnim pobudzeniem seksualnym młodych dziewcząt. Warto przytoczyć tutaj fragment analizy tego zjawiska, zaproponowany przez Jana Bieleckiego z Komendy Stołecznej MO: „przyczynia się również do tego rozwiązły tryb życia spotykany w małżeństwach. Zdarza się często, że żony z takich związków powiększają liczbę prostytutek. [...] Jako następną z przyczyn powstawania prostytucji można wymienić nienormalny stosunek do spraw płciowych ze strony dziewcząt o określonych cechach psychopatycznych i słabej woli. [...] Jeśli taka dziewczyna dostanie się w złe otoczenie, przeważnie nie umie wrócić na właściwą drogę i staje się prostytutką" ${ }^{37}$. Niemoralne prowadzenie mogło jednak według milicjantów

${ }^{35}$ S. Górnicki, op. cit., cz. 1, s. 23.

${ }^{36}$ J. Bielecki, Z praktyki jednostek MO. Prostytucja i nierząd karalny w Warszawie, „Służba MO” 1959, nr 3(12), s. 432.

${ }^{37}$ Ibidem, s. 433. 
dotyczyć również dziewcząt z tzw. dobrych rodzin, dla których przyczyną rozpoczęcia pracy prostytutki była chęć posiadania pieniędzy na cele konsumpcyjne. Grupa ta została określona przez Górnickiego w następujący sposób: ,jest także pewna część dziewcząt (nawet $\mathrm{z}$ rodzin prowadzących moralny tryb życia i nieźle sytuowanych), które wchodzą na drogę prostytucji z chęci wyżycia się. Dziewczęta te, niejednokrotnie bardzo młode, bywają w różnych lokalach [...] nie mając zaś środków na modne stroje i zabawy, zaczynają uprawiać nierząd"38. Dla takich kobiet prostytucja była często zajęciem dorywczym, które dopiero po pewnym czasie mogło się przerodzić w stałą „pracę”. To praca profilaktyczna $\mathrm{z}$ tą grupą kobiet stanowiła według milicjantów najpilniejsze działanie $\mathrm{w}$ walce ze zjawiskiem prostytucji.

Tendencją obecną w milicyjnych analizach było również łączenie prostytucji z patologiami społecznymi, a także przestępstwami. W opracowaniu autorstwa Górnickiego czytamy: „znaczna większość prostytutek rekrutuje się z najniższych warstw społeczeństwa, $\mathrm{z}$ rodzin moralnie zdeprawowanych, związanych ze środowiskami przestępczymi, które niejednokrotnie kształtują osobowość przyszłej prostytutki" ${ }^{39}$. Te analizy zdają się znajdować potwierdzenie w informacjach zdobytych od samych prostytutek. $Z$ danych zebranych przez warszawską sekcję do walki z nierządem wynika, że największa grupa prostytutek, z którymi prowadzono na ten temat rozmowy, jako przyczyny podjęcia przez siebie tej pracy wskazywała (oprócz omówionych już wyżej złych warunków materialnych) wpływ otoczenia społecznego ${ }^{40}$. Wyniki ankiety przeprowadzanej przez sekcję do walki z nierządem należy oczywiście traktować z nieufnością. Nie znamy warunków, w których przeprowadzano rozmowy z prostytutkami, a także tego, jak dużą dowolność miały w odpowiadaniu (np. czy pytania miały formę otwartą, czy raczej to milicjant przeprowadzający ewidencję proponował prostytutce odpowiedzi). Warto również zauważyć, że grupa prostytutek, od których zebrano te dane, $\mathrm{z}$ pewnością nie była reprezentatywna. Ewidencję przeprowadzano tylko wśród kobiet zatrzymanych przez milicjantów, na pewno więc obecne są w niej w szczególności te, które $\mathrm{w}$ jakiś sposób naruszały porządek publiczny lub były powiązane ze środowiskami przestępczymi i zostały skontrolowane $\mathrm{z}$ tego powodu. W ewidencji nie znajdziemy też prostytutek „luksusowych”, których działalność wymykała się możliwościom milicyjnego opisu, ponieważ nie poszukiwały swoich klientów w zwykłych lokalach rozrywkowych czy melinach kuplerskich. Mimo to warto przyjrzeć się tej ankiecie jako świadectwu pewnej wizji

\footnotetext{
38 S. Górnicki, Prostytucja a przestępczość, cz. 2, „Służba MO” 1963, nr 1 (35), s. 224.

${ }^{39}$ S. Górnicki, op. cit., cz. 1, s. 33.

${ }^{40}$ AKSP, ADM-1474, Sprawozdanie z działalności Sekcji do walki z Nierządem i jednostek M.O. m.st. Warszawy w zakresie ścigania przestępstw nierządu karalnego i ograniczania prostytucji, 1961, k. 2.
} 
prostytucji, jaką posiadali milicjanci i która z pewnością wpływała na podejmowane przez nich działania.

Jednak nie wszyscy milicjanci uważali prostytutki za ofiary złej sytuacji ekonomicznej czy przedstawicielki „marginesu” społecznego. Wraz z rozwojem instytucjonalnym sekcji ds. walki z nierządem, a także stabilizacją sytuacji społecznej i względnym poprawieniem się jakości życia, zaczęto dostrzegać nowe zjawisko. W milicyjnych analizach lat sześćdziesiątych pojawia się niekiedy pojęcie „nierządu zawodowego". Nie chodzi tutaj jednak tylko o dosłowne rozumienie tego słowa, w którym pobieranie opłaty za usługi czyni z prostytutki „przedsiębiorcę”41. Pod pojęciem „zawodu” używanym przez milicjantów kryje się określona wizja motywacji, które popchnęły prostytutkę do rozpoczęcia pracy w tym charakterze. „Wyjaśnienia te [dotyczące przyczyn materialnych - przyp. A.D.] - są w wielu wypadkach zbyt jednostronne, ponieważ poważna część znanych nam prostytutek przystąpiła do uprawiania tego procederu, traktując go jako pewnego rodzaju zawód, choć żyła w nie najgorszych wcale warunkach materialnych. Tłumaczą one, że pragnęły zamożniej żyć, zawsze modnie się ubierać, mieć pieniądze, bawić się. Widziały tylko jedną drogę do osiągnięcia tego celu: prostytucję. Te motywy na pewno nie znajdą u nas zrozumienia, zwłaszcza, że stykamy się tu z kobietami młodymi, zdrowymi, nierzadko mającymi średnie wykształcenie" 42 . Dla tej grupy prostytutek „nierząd” stał się narzędziem swoistej emancypacji ekonomicznej. Nie był koniecznością wynikającą ze złej sytuacji materialnej, a raczej świadomą decyzją wyboru określonej drogi do osiągnięcia celu, jakim było poprawienie statusu materialnego. Ciekawa wydaje się postawa milicjantów wobec tych kobiet. $\mathrm{O}$ ile te, które uprawiały prostytucję ze względu na problemy materialne czy pochodzenie $z$ „marginesu” społecznego, mogły liczyć na swego rodzaju współczucie ze strony funkcjonariuszy i autorów opracowań, to prostytutki „zawodowe” znajdowały się absolutnie poza obszarem zachowań akceptowalnych. Kobieca seksualność podlegała ścisłej kontroli społecznej i w oczach wielu powinna ograniczać się do ram wyznaczanych przez małżeństwo. Kobiety wykraczające poza „normalne” seksualne zachowania były poddawane ostracyzmowi społecznemu, co z pewnością miało wpływ na stosunek milicjantów do prostytutek. W tej wizji akceptowalnych praktyk seksualnych nie ma miejsca dla kobiet, które świadomie i swobodnie wykorzystują swoją seksualność do osiągnięcia materialnych korzyści.

Prostytucja, jako zjawisko powiązane ze sferą seksualności i silnie stabuizowane, podlegała milicyjnym ocenom również w warstwie moralnej. W oficjalnych dokumentach stosunek milicjantów do prostytutek można określić jako przyjazny. Omówione wcześniej przykłady wskazują, że przynajmniej część funkcjonariuszy starała się zrozumieć przyczyny, dla których kobiety decydowały się zostać

\footnotetext{
41 Por. K. Matysiak, op. cit., s. 342.

${ }^{42}$ J. Bielecki, op. cit., s. 432.
} 
prostytutkami, a także pomóc im w zmianie sposobu życia. Nie dotyczyło to z pewnością wszystkich milicjantów, można wręcz podejrzewać, że dominującymi reakcjami, z którymi spotykały się na posterunkach i komendach prostytutki, były wyzwiska, pogarda czy przemoc. Na pewno częściowo wynikało to z braku ogólnospołecznej akceptacji dla ich pracy. W oficjalnych milicyjnych opracowaniach również znajdziemy moralne oceny tego zjawiska. W artykule Jana Bieleckiego czytamy: „Uczestnicy dyskusji widzą jedną z przyczyn rodzenia się prostytucji w panujących w społeczeństwie poglądach moralnych i obyczajowych. Istnienie prostytucji jest wyrazem nieposzanowania godności ludzkiej ze strony przedstawicieli obojga płci. [...] Wszyscy dotychczas wypowiadający się na łamach prasy na temat prostytucji $\mathrm{w}$ naszym kraju podkreślali szkodliwość społeczną tego zjawiska. Istnienie prostytucji nie jest zgodne z panującymi w społeczeństwie socjalistycznym zasadami etyki i moralności, a odpłatny stosunek fizyczny jest upokorzeniem zarówno dla kobiety, jak i dla mężczyzny. Prostytutka jest świadectwem upodlenia człowieka" ${ }^{43}$. Warto podkreślić tutaj, że moralna ocena zarówno prostytutki, jak i jej klienta, obecna w omawianym fragmencie, nie była częstym zjawiskiem $\mathrm{w}$ milicyjnych analizach na temat prostytucji. W większości przypadków ci drudzy byli po prostu nieobecni.

Jak wynika z omówionych w artykule źródeł, istniało wiele cech, na których podstawie można było stwierdzić, że dana kobieta jest prostytutką. Często wiązało się to $\mathrm{z}$ wpisaniem jej do rejestru, w którym ewidencjonowano kobiety zajmujące się nierządem $\mathrm{z}$ danej miejscowości - oficjalnie w celach przeciwdziałania innym przestępstwom i pomocy w zmianie trybu życia. Warto więc zastanowić się, w jaki sposób wpisana do takiego rejestru kobieta mogła w oczach milicjantów przestać być prostytutką. Ciekawej odpowiedzi dostarczają źródła. Według Górnickiego „W roku 1957 wyeliminowano z ewidencji 233 prostytutki w związku z wyjściem za mąż, podjęciem pracy lub powrotem do rodziców"44. Informacje na ten temat znajdziemy również w sprawozdaniu warszawskiej sekcji do walki z nierządem za rok 1969. Milicjanci raportują, że z ewidencji wykreślonych zostało 17 prostytutek, z czego 10 wyszło za mąż (w tym 5 za cudzoziemca), 3 zmarły, a 4 przestały zajmować się prostytucją i podjęly pracę ${ }^{45}$. Jak widać, w oczach milicjantów wyjście za mąż było jednym z kluczowych sposobów na zerwanie z nierządem. Być może łączyło się to z przekonaniem, że kobieta posiadająca męża (a więc będąca też na jego utrzymaniu) straci motywację finansową do zajmowania się prostytucją. Co więcej, wzmianka o cudzoziemcach może po raz kolejny sugerować, że dla wielu prostytutek nierząd był narzędziem poprawy swojej pozycji materialnej i społecznej (w dokumentach pojawia się informacja, że kobiety te wyjechały z kraju

${ }^{43}$ J. Bielecki, op. cit., s. 433.

${ }^{44}$ S. Górnicki, op. cit., cz. 2, s. 228.

${ }^{45}$ AKSP, ADM-1796, Sprawozdanie za działalność w 1969 r. Sekcji d/w z Nierządem Komendy Stołecznej MO w zakresie ścigania przestępstw nierządu karalnego i ograniczania prostytucji, k. 7. 
razem ze swoimi mężami). Interesującym uzupełnieniem tego obrazu jest informacja o prostytutkach, które wróciły do domów rodzinnych. Wskazuje na dosyć tradycyjne postrzeganie miejsca kobiety w społeczeństwie, wyznaczanego przez kontrolę ze strony tradycyjnych instytucji takich jak rodzina czy małżeństwo. Ten fragment może być też dowodem na istnienie zjawiska „nieudanej migracji” do miast. Młode, przyjeżdżające ze wsi kobiety, którym nie udało się znaleźć pracy, mogły rozpoczynać pracę jako prostytutki - w tym wypadku drogą do zerwania z procederem był właśnie powrót do domu rodzinnego.

\section{Typologia}

Prostytutki to grupa niehomogeniczna, która, jak już zauważono wcześniej, nie poddaje się prostemu opisowi. Świadomość tę mieli również sami milicjanci, którzy na potrzeby działań operacyjnych tworzyli różnorodne typologie. Podstawowym kryterium podziału było miejsce nawiązywania kontaktów z klientami, a także miejsce późniejszego odbycia stosunków z nimi. To od tych czynników zależała pozycja prostytutki w nieformalnej hierarchii, a także sposób postrzegania jej przez funkcjonariuszy MO.

W najgorszej sytuacji były prostytutki uliczne, zwane również „gruzinkami”, które Bielecki opisał w następujący sposób: „nazwa ta pochodzi stąd, że w pierwszych latach po wyzwoleniu prostytutki gnieździły się i uprawiały nierząd w gruzach. Są to w przytłaczającej większości prostytutki starsze wiekiem. [...] Wśród «gruzinek» jest najwięcej bezdomnych i chorych. [...] Klientów oczekują na ulicach mających pod tym względem ustaloną tradycję, jak np. Hoża, Krucza, Nowogrodzka, Chmielna, Targowa. Można je też dość często spotkać w pobliżu lokali rozrywkowych i dworców, zwłaszcza na Pradze"46. Warto zwrócić uwage na język wykorzystany przez autora do opisu tej grupy prostytutek. Szczególnie słowo „gnieździły się" wskazuje na swego rodzaju odczłowieczenie tych kobiet, a także podkreśla ich złe warunki życiowe. Są one również skojarzone z różnego rodzaju patologiami - przede wszystkim chorobami (prawdopodobnie wenerycznymi) i bezdomnością. Ciekawe są również wymienione przez autora lokalizacje, w których spotkać można „gruzinki”. Kojarzą się one z mniej reprezentacyjnymi rejonami Warszawy, które, jak np. Praga, są w powszechnej opinii siedliskiem patologii i braku moralności. Obraz dopełniony został informacją o wieku kobiet - co prawdopodobnie oznaczać ma również, że nie należą one według milicjantów do najbardziej urodziwych. Wskazują na to informacje pojawiające się chociażby w opracowaniu Górnickiego, który mówi o osobnej podkategorii „rosówek”, czyli prostytutek, które pracowały tylko w nocy, w słabiej oświetlonych miejscach,

\footnotetext{
${ }^{46}$ J. Bielecki, op. cit., s. 431.
} 
co wynika według niego z ich „powierzchowności lub wieku”47. Oprócz określenia „gruzinki”, funkcjonowały również inne, regionalne nazwy: „mewki” (miasta portowe), „syrenki” (Warszawa), a także „iwonki” (w Łodzi) ${ }^{48}$.

Drugą największą grupą wyróżnianą przez milicjantów były tzw. lokalówki. Określenie to pochodziło od miejsca nawiązywania przez te prostytutki kontaktów z klientami - były to różne lokale rozrywkowe, kawiarnie i restauracje. Stosunki z klientami odbywały się później w wynajętych mieszkaniach, pokojach hotelowych, a w przypadku biedniejszej grupy „lokalówek” - w melinach kuplerskich lub mieszkaniach sutenerów. Górnicki zwraca uwagę, że cechą charakterystyczną tych prostytutek był „artystyczny”, elegancki ubiór i „kokieteria”49. Z kolei w opracowaniu Bieleckiego o warszawskich prostytutkach możemy przeczytać, że: „Wiek ich nie przekracza zwykle 30 lat, są przeważnie dość przystojne, ubierają się zazwyczaj dobrze i modnie. Szukają one klientów najczęściej w kawiarniach i w nocnych lokalach rozrywkowych. [...] Poważną rolę w zawieraniu znajomości odgrywają stręczyciele, a nieraz kelnerzy i szatniarze. $\mathrm{W}$ tej sytuacji nawiązywanie w lokalach kontaktów z mężczyznami, nie sprawia prostytutkom trudności, zwłaszcza że niektórzy z nich tylko w tym celu tu przychodzą. [...] Jeśli «lokalówki» udają się bezpośrednio do nocnych lokali w celu pozyskania «klientów», to towarzyszą im zwykle mężczyźni z półświatka, zwykle stręczyciele lub sutenerzy, których prostytutki przedstawiają jako swych narzeczonych lub znajomych"50. Wskazuje on także, że ten rodzaj prostytucji połączony być mógł z dosyć wysokimi zarobkami, które pozwalały na jeżdżenie taksówkami i „ładne ubieranie się" ${ }^{1}$. Można więc podsumować, że w oczach milicjantów cechami wyróżniającymi prostytutki lokalowe był ładny wygląd, dobre ubranie, wiek, a także współpraca z różnego rodzaju „opiekunami”. Cały proceder skupiać się miał wokół lokali rozrywkowych, które w opinii milicjantów stanowiły największe zagrożenie dla publicznej moralności.

Inne typy prostytutek nie zostały tak dokładnie opisane. Tak duża ilość miejsca poświęcona „lokalówkom” i „gruzinkom” może wynikać z tego, że to z nimi milicjanci spotykali się najczęściej i mieli największe doświadczenie i wiedzę na ich temat. Warto również zauważyć, że inne typy prostytutek pojawiają się dopiero w opracowaniu Górnickiego, które pochodzi z 1963 r. Mogło to wynikać z poprawienia się sytuacji materialnej, zarówno prostytutek, jak i ich klientów, i związanej z tym zmiany w charakterze usług. Drugim wytłumaczeniem „pojawienia się" nowych typów prostytutek jest doświadczenie i wiedza nabyte przez działające wtedy już od kilku lat sekcje ds. walki z nierządem. Być może w wyniku

\footnotetext{
${ }^{47}$ S. Górnicki, op. cit., cz. 1, s. 24.

${ }^{48}$ Ibidem.

${ }^{49}$ Ibidem.

${ }^{50}$ J. Bielecki, op. cit., s. 430.

${ }^{51}$ Ibidem, s. 431.
} 
zintensyfikowanej działalności operacyjnej milicjanci odkryli nowe rodzaje prostytucji, z którymi wcześniej się nie spotykali. „Spośród prostytutek zaewidencjonowanych w milicji około $80 \%$ stanowią prostytutki uliczne i te «lokalówki», które zawierają znajomość w podrzędnych lokalach. Natomiast pozostałe $20 \%$ stanowią prostytutki lokalowe, hotelowe i towarzyskie" 52 - czytamy w artykule Górnickiego. Prostytutki hotelowe definiował on jako kobiety działające poza miejscem swojego zamieszkania, zwykle $\mathrm{w}$ dużych miastach, a w zdobywaniu klientów często korzystające z pomocy portierów hotelowych. Ostatnia wymieniona grupa, prostytutki towarzyskie, została opisana najzwięźlej, co może potwierdzać tezę o małej wiedzy, jaką posiadali o nich milicjanci. Były to kobiety, które klientów przyjmowały w swoich mieszkaniach, a rekrutowały ich na podstawie znajomości i przebywania w odpowiednich kręgach. Górnicki zauważa, że ich mieszkania (nazywane w terminologii milicyjnej „domami schadzek”) były „dobrze urządzone", a one same zachowywały się "taktownie i kulturalnie”. Za pomocą tych określeń wyraźnie wyznacza granicę między prostytutkami ulicznymi, brudnymi i zdegenerowanymi, a tymi kulturalnymi, poruszającymi się w dobrym towarzystwie. Choć charakter ich działalności pozostaje ten sam, w oczach milicjanta należą do dwóch różnych światów.

\section{Problemy powiązane}

„Obok stręczenia i odstępowania mieszkania dla celów nierządnych ujawniono wiele przypadków kradzieży pieniędzy w melinach na szkodę osób korzystających z usług prostytucji, przypadki spekulacji, nielegalnego przerywania ciąży, zarażenia świadomego chorobą weneryczną, wykroczeń p-ko ustawie antyalkoholowej itp." ${ }^{33}$ - czytamy w jednym z rozkazów. Na podstawie analizy dokumentów milicyjnych można stwierdzić, że funkcjonariusze nie traktowali prostytucji jako samodzielnego problemu, ale wiązali ją z różnorodnymi zjawiskami. Chodzi zarówno o przyczyny prostytucji, które omówione zostały we wcześniejszej części artykułu, jak też o jej skutki i zjawiska towarzyszące. Niemal zawsze poruszanie tematu musiało wiązać się ze zwróceniem uwagi na powiązania prostytucji z przestępczością i patologiami społecznymi. Trudno powiedzieć, na ile wynikało to $\mathrm{z}$ uprzedzeń i stereotypów, a na ile z doświadczeń pracy w terenie. Na pewno warto jednak zwrócić uwagę na kilka zjawisk, z którymi łączona była prostytucja. Pierwszym z nich była przestępczość. W sprawozdaniu Komendy Stołecznej MO za rok 1960 czytamy: „dokładna obserwacja interesujących osób, rejestrowanie o nich wszechstronnych danych pozwoliło ustalić, że kobiety trudniące się zawodowo uprawianiem nierządu oprócz tego procederu dokonują bezpośrednio

\footnotetext{
${ }^{52}$ S. Górnicki, op. cit., cz. 1, s. 25.

${ }^{53}$ GAP, 4/89 t. 1, Projekt rozkazu specjalnego nr 49/61 KGMO, k. 500-502.
} 
lub $\mathrm{w}$ powiązaniu $\mathrm{z}$ innymi osobami różnego rodzaju przestępstw, jak również w dość licznych wypadkach dopuszczają się różnego rodzaju wykroczeń (najczęściej wybryki chuligańskie)" ${ }^{24}$. Na podstawie tego typu sprawozdań można wyróżnić dwie kategorie, którymi posługiwali się milicjanci. Po pierwsze, łączyli oni prostytucję z różnego rodzaju przestępstwami przeciwko mieniu, przede wszystkim kradzieżami ${ }^{55}$. Zauważano udział prostytutek w napadach rabunkowych, w których pełniły funkcję tzw. wabika. Zwracano uwagę na wykorzystywanie klientów w intymnych sytuacjach ${ }^{56}$. Po drugie, prostytutki często karane były za wykroczenia związane $\mathrm{z}$ naruszaniem porządku publicznego. Wynikało to wprost z rozkazu komendanta głównego MO, który nakazywał: „energicznie reagować na wypadki wystawania prostytutek na ulicach i zaczepiania przez nie mężczyzn, wulgarnego zachowania się w miejscu publicznym, zakłócania spokoju publicznego, nieobyczajnych wybryków, używania słów nieprzyzwoitych, a także uchylania się od obowiązku leczenia choroby wenerycznej" ${ }^{57}$. Warto również zauważyć, że w kwestionariuszu, który wypełniać mieli funkcjonariusze zatrzymujący prostytutki, dużo miejsca poświęcono przestępstwom, za które karane były wcześniej kobiety ${ }^{58}$. Jako podsumowanie tego milicyjnego dyskursu można przytoczyć cytat z jednego z opracowań: „okres uprawiania prostytucji jest wprost proporcjonalny do liczby sądownie karanych prostytutek. Innymi słowy - im dłużej prostytutka zajmuje się nierządem, tym więcej popełnia przestępstw"59.

Poza przestępczością, ważnym problemem społecznym ściśle związanym z prostytucją były choroby weneryczne. Jak pisano, „każdemu wzrostowi prostytucji towarzyszy wzrost chorób wenerycznych, których nosicielami są zarówno kobiety, jak i mężczyźni”60. Obawa przed taką epidemią towarzyszyła funkcjonariuszom zajmującym się problematyką nierządu właściwie od początku istnienia Milicji Obywatelskiej. Problem ten nie był jednak nowy - choroby weneryczne łączono z prostytucją od zawsze, a już w XIX w. podejmowano instytucjonalne działania

\footnotetext{
${ }^{54}$ AKSP, ADM-1482, Sprawozdanie z pracy Wydziału Sł. Kryminalnej Komendy MO m.st. Warszawy za trzy kwartały 1960 r., k. 64.

${ }^{55}$ Por. GAP, 4/89 t. 1, Rozkaz specjalny KGMO nr 49/61 z dn. 6 VII 1961, k. 497-498; W. Jura, Z praktyki jednostek MO. Zabójstwo prostytutki, „Służba MO” 1964, nr 1 (40), s. 58-67; AKSP, ADM-1474, Sprawozdanie z działalności Sekcji do walki z Nierządem i jednostek M.O. m.st. Warszawy w zakresie ścigania przestępstw nierządu karalnego i ograniczania prostytucji za rok 1960, k. 11-12.

${ }^{56}$ S. Górnicki, op. cit., cz. 1, s. 29.

${ }^{57}$ GAP, 4/59, Rozkaz Komendanta Głównego Milicji Obywatelskiej z dn. 23 I 1956 nr 2/56 w sprawie wzmożenia walki z prostytucją, k. 20.

${ }^{58}$ Por. AKSP ADM-1474, Sprawozdanie z działalności Sekcji do Walki z Nierządem i jednostek M.O. m.st. Warszawy w zakresie ścigania przestępstw nierządu karalnego i ograniczania prostytucji za rok 1960, k. 5.

${ }^{59}$ S. Górnicki, op. cit., cz. 2, s. 225.

${ }^{60}$ J. Bielecki, op. cit., s. 434.
} 
mające powstrzymywać ich rozprzestrzenianie się, np. wydawano prostytutkom „czarne książeczki”. W okresie powojennym szczególne nasilenie działań milicji przypadło na lata 1948-1949, kiedy prowadzona była tzw. akcja „W”61. Początkowo alarmowano, że zarażonych chorobami wenerycznymi może być nawet 200 tys. obywateli. Szybko okazało się jednak, że akcja miała znamiona paniki moralnej ${ }^{62}$, a prawdziwa liczba zarażonych była w rzeczywistości dużo niższa. Strach przed epidemią i ścisłe powiązanie tej problematyki z prostytucją pozostały jednak na dłużej i wpłynęły na stosunek milicjantów do kobiet zajmujących się „nierządem”. Oczywiście warto tutaj uwzględnić drugi czynnik wpływający na takie postawy - był to również spadek po systemie reglamentacyjnym i neoreglamentacyjnym, w którym prostytutki musiały być poddawane regularnym kontrolom lekarskim pod kątem chorób wenerycznych.

„Wzrost chorób wenerycznych występuje szczególnie w Warszawie oraz w województwach: katowickim, krakowskim, gdańskim i szczecińskim. [...] Przy zwalczaniu rozszerzania się chorób wenerycznych zbyt małą rolę odgrywają dotychczas środki represji karnej" ${ }^{63}$ - pisał Stanisław Górnicki. O jakie środki chodziło autorowi? Funkcjonariusze odwoływali się przede wszystkim do art. 245 k.k., który wyznaczał karę za narażanie innych na zarażenie chorobą weneryczną, nawet jeżeli nie nastąpiło samo zarażenie ${ }^{64}$. Powoływali się również na dekret o zwalczaniu chorób wenerycznych z 16 kwietnia 1946 r., który zezwalał na przymusowe leczenie osób chorych, jeżeli nie chciały same stawić się odpowiednich przychodniach ${ }^{65}$. Zagrożenie chorobami wenerycznymi zauważano również $\mathrm{w}$ analizach dotyczących nieletnich. W rozkazie poświęconym milicyjnym izbom dziecka możemy przeczytać, że „jeśli stan zdrowia małoletniego budzi wątpliwości (np. podwyższona temperatura, objawy nasuwające podejrzenie chorób skórnych, przebywanie w środowisku zagrożonym chorobami zakaźnymi, zwłaszcza wenerycznymi) małoletniego należy umieścić w odrębnym pomieszczeniu (izolatka sanitarna) do czasu zasięgnięcia opinii lekarza"66. Demoralizację nieletnich wiązano z przebywaniem w niewłaściwych środowiskach (np. w otoczeniu prostytutek, w melinach kuplerskich). Szczególnym obiektem zainteresowania milicjantów było zapobieganie demoralizacji młodych dziewcząt ${ }^{67}$. Do ich

${ }^{61} \mathrm{Na}$ temat akcji „W” patrz: P. Barański, Walka $z$ chorobami wenerycznymi w Polsce w latach 19481949, w: Kłopoty z seksem w PRL, red. M. Kula, Warszawa 2012.

${ }^{62}$ Por. E. Goode, N. Ben-Yehuda, Moral Panics. The Social Construction of Deviance, Oxford 2009.

${ }^{63}$ S. Górnicki, op. cit., cz. 2, s. 226.

${ }^{64}$ GAP, 74x/4, Rozkaz nr 3/59 z dn. 6 II 1959 - Wytyczne ws. ścigania przestępstw nierządu karalnego, przeciwdziałania prostytucji oraz współudziału organów MO w zwalczaniu chorób wenerycznych, s. 5, 8-9.

${ }^{65}$ Ibidem, s. 7.

${ }^{66}$ GAP, 4/113, Rozkaz KGMO nr 1/67 z dn. 10 II 1967 w sprawie milicyjnych izb dziecka, s. 8.

${ }^{67}$ AKSP, ADM-1486, Sprawozdanie i ocena pracy pionu kryminalnego m.st. Warszawy za rok 1961, k. 36 . 
zadań miało np. należeć informowanie izb dziecka lub inspektorów ds. nieletnich o młodocianych uprawiających prostytucję ${ }^{68}$. Milicjanci zwracali też uwagę na konieczność seksualnej edukacji młodzieży i położenia nacisku na uświadamianie, że ryzyko chorób wenerycznych jest ściśle powiązane z prostytucją ${ }^{69}$.

Jednym $\mathrm{z}$ elementów ankiety uzupełnianej przez milicjantów $\mathrm{w}$ ramach ewidencjonowania prostytutki była rubryczka: „czy jest nałogowym alkoholikiem"70. W sprawozdaniach $\mathrm{z}$ działalności sekcji do walki z nierządem widać, że liczba prostytutek mających problemy z alkoholem była stale wysoka. Dla przykładu, w Warszawie w 1960 r. zarejestrowano 217 nałogowych alkoholiczek (na 990 wszystkich zarejestrowanych). W roku 1969 ten stosunek był nieco niższy i wynosił 191 alkoholiczek na 1685 kobiet $^{71}$. Warto zauważyć, że w statystykach uwzględniano wyłącznie nałogowych alkoholików (nie podano jednak dokładnej informacji, w jaki sposób definiowano takie uzależnienie). Liczba prostytutek nadużywających alkoholu była prawdopodobnie jeszcze wyższa. W interpretacji tych danych dodatkową trudnością jest fakt, że tolerancja na spożywanie alkoholu w PRL-u była dużo wyższa nich współcześnie, trudno więc wyznaczyć granicę „normalnego” spożycia alkoholu ${ }^{72}$. Pewne jest jedno obok powiązań z przestępcami i chorób wenerycznych, był to kolejny problem społeczny ściśle wiązany przez milicjantów z prostytucją. Zauważano, że jest to czynnik podtrzymujący prostytucję i umożliwiający jej rozwój ${ }^{73}$. Alkoholizm wiązał się również ściśle z problemem naruszania porządku publicznego. „Wiadomym jest, że spokój i porządek najczęściej zakłócają osoby będące w stanie nietrzeźwym i prostytutki" ${ }^{\prime 4}$ - taką diagnozę prezentowano w notatce dotyczącej „elementu uciążliwego” w Warszawie. W milicyjnych rozkazach zwracano uwagę, że narzędziem do walki z prostytucją powinna być ustawa antyalkoholowa, zezwalająca na karanie za zakłócanie porządku publicznego przez osoby znajdujące się pod wpływem alkoholu, ale także na doprowadzanie ich do izb wytrzeźwień i przymusowe leczenie alkoholików ${ }^{75}$. Łączenie alkoholizmu

${ }^{68}$ GAP, 74x/4, Rozkaz nr 3/59 z dn. 6 II 1959 - Wytyczne ws. ścigania przestępstw nierządu karalnego, przeciwdziałania prostytucji oraz współudziału organów MO w zwalczaniu chorób wenerycznych, s. 11.

${ }^{69}$ S. Górnicki, op. cit., cz. 2, s. 236.

${ }^{70} \mathrm{GAP}, 74 \mathrm{x} / 4$, Załącznik do rozkazu nr 3/59, Ankieta statystyczna.

${ }^{71}$ AKSP, ADM-1796, Sprawozdanie za działalnośćw 1969 r. Sekcjid/w z Nierządem komendy Stołecznej MO w zakresie ścigania przestępstw nierządu karalnego i ograniczania prostytucji, k. 1-22, s. 1, 6 .

${ }^{72}$ Por. K. Kosiński, Historia pijaństwa..., passim.

${ }^{73}$ S. Górnicki, op. cit., cz. 1, s. 33.

${ }^{74}$ AKSP, ADM-1475, Notatka informacyjna dot. elementu uciążliwego zam. na terenie m.st. Warszawy, którym są zainteresowane organa MO, 1961, k. 2, 4-6, 10-11, s. 9.

${ }^{75}$ AGP, 74x/4, Rozkaz nr 3/59 z dn. 6 II 1959 - Wytyczne ws. ścigania przestępstw nierządu karalnego, przeciwdziałania prostytucji oraz współudziału organów MO w zwalczaniu chorób wenerycznych, s. 6-7. 
z prostytucją wynikało również z kontekstu społecznego, w którym funkcjonowały prostytutki. Lokale rozrywkowe czy meliny to miejsca, w których sprzedawano alkohol, często nielegalnie.

Kradzieże, naruszenia porządku publicznego, choroby weneryczne, demoralizacja nieletnich i alkoholizm - tak w skrócie naszkicować możemy pola semantyczne, które funkcjonariusze MO konotowali ze zjawiskiem prostytucji. Nie do rozstrzygnięcia na obecnym etapie badań jest kwestia, na ile pola te znajdywały odwzorowanie w rzeczywistości, a na ile zostały stworzone przez funkcjonariuszy, jako narzędzie do opisywania i porządkowania świata, z którym się stykali. $\mathrm{Na}$ pewno warto zauważyć, że definiowanie prostytucji poprzez powiązane patologie społeczne miało niewątpliwie funkcję praktyczną - pozwalało milicjantom na znalezienie metod karania prostytutek i zwalczania nierządu. Obowiązujące, abolicjonistyczne przepisy prawa karnego nie traktowały samej prostytucji jako przestępstwa, a więc do walki z tym procederem trzeba było stosować inne narzędzia.

\section{Wnioski}

Analiza dokumentów milicyjnych dotyczących prostytucji pozwala na wyciągnięcie kilku ważnych wniosków na temat kształtu tego zjawiska w latach sześćdziesiątych XX w. Po pierwsze, z pewnością możemy w tym okresie obserwować tworzenie się milicyjnego dyskursu eksperckiego. Choć czerpał on z języka i metod wykorzystywanych np. przez policję w II RP, to zauważyć możemy proces kształtowania się nowych ram interpretacji zjawiska prostytucji. W dokumentach widać, jak doświadczenia z pracy operacyjnej przekładają się na quasi-naukowe analizy i rekomendacje dotyczące podejmowanych działań. Zaobserwować możemy też ścieranie się różnych koncepcji postrzegania zjawiska i tworzenie definicji. Można wyciągnąć wniosek, że postrzeganie prostytucji przez milicjantów podlegało zmianom i było negocjowane w procesie pracy operacyjnej, a także dostosowywane do potrzeb wynikających z pracy w terenie.

Po drugie, na podstawie przeprowadzonej analizy można określić pola semantyczne, które funkcjonariusze MO wiązali z problemem prostytucji. Można wśród nich wymienić przestępczość, alkoholizm, choroby weneryczne, demoralizację nieletnich i zakłócanie porządku publicznego. Zjawiska te były wykorzystywane przez milicjantów jako pretekst do karania prostytutek za wykroczenia i przestępstwa mimo obowiązującego prawa, które nie penalizowało prostytucji i zakazywało rejestrowania kobiet pracujących w ten sposób. W ich oczach służyło to jednak przeciwdziałaniu samej prostytucji. Dużo mniejszym zainteresowaniem milicjantów cieszyły się osoby czerpiące korzyści finansowe z prostytucji (sutenerzy, kuplerzy). Z kolei klienci korzystający z usług prostytutek są właściwie niewidoczni w milicyjnych analizach. 
Milicyjne dokumenty i publikacje z pewnością wymagają analizy z perspektywy krytyki feministycznej. Na podstawie moich badań można postawić tezę, że wpływ na stosunek milicjantów do prostytucji miała tradycyjna wizja kobiecej seksualności. Jednak czynników wpływu było więcej: okoliczności polityczne, przemiany społeczne i poprawa sytuacji materialnej społeczeństwa, a także ideologiczne umocowanie walki z prostytucją. Wszystkie te zależności powinny stanowić przedmiot dalszej krytycznej analizy.

\section{A problem that was supposed to disappear. The language of the Civic Militia documents concerning prostitution (1956-1969) (Abstract)}

History of prostitution is both a fascinating and a controversial topic. Yet, it still has not been thoroughly researched by historians, especially when it comes to the postwar history of Poland. The purpose of his article is to deepen our understanding of prostitution in the postwar Poland. To achieve that the author has analysed the language used by the Civic Militia (Polish: Milicja Obywatelska) to describe this phenomenon in the 1960s. Both the methods of historical source analysis and historical sociology are used to accomplish that. The sources include written orders, reports and notes produced by the Civic Militia officers and stored in the Police archives. Furthermore, the professional journals such as the Stużba MO have been carefully researched to observe the development of a specific expert discourse on prostitution. The language of these texts turns out to be deeply rooted in the traditional vision of female sexuality. On the other hand, the sources show a visible change in the Civic Militia's attitude towards prostitution and the professionalisation of its operations.

\section{Bibliografia}

\section{Źródła}

AGP, 4/89 t. 1, Rozkaz specjalny KGMO nr 49/61 z dn. 6 VII 1961, k. 497-498

AGP, 4/89 t. 1, Projekt rozkazu specjalnego nr 49/61 KGMO, k. 500-502

AKSP, ADM-1474, Sprawozdanie z działalności Sekcji do Walki z Nierządem i jednostek M.O. m.st. Warszawy w zakresie ścigania przestępstw nierządu karalnego i ograniczania prostytucji za rok 1960, k. 2-19

AKSP, ADM-1475, Notatka informacyjna dot. elementu uciążliwego zam. na terenie m.st. Warszawy, którym są zainteresowane organa MO, 1961, k. 2, 4-6, 10-11

AKSP, ADM-1482, Sprawozdanie z pracy Wydziału Sł. Kryminalnej Komendy MO m.st. Warszawy za trzy kwartały 1960 r., k. 1, 59-65

AKSP, ADM-1486, Sprawozdanie i ocena pracy pionu kryminalnego m.st. Warszawy za rok 1961, k. $10,44-45,50$

AKSP, ADM-1796, Sprawozdanie za działalność w 1969 r. Sekcji d/w z Nierządem Komendy Stołecznej MO w zakresie ścigania przestępstw nierządu karalnego i ograniczania prostytucji, k. $1-22$

Bielecki J., Z praktyki jednostek MO. Prostytucja i nierzad karalny w Warszawie, „Służba MO” 1959, nr 3(12)

Górnicki S., Prostytucja a przestępczość, cz. 1, „Służba MO” 1963, nr 1 (34)

Górnicki S., Prostytucja a przestępczość, cz. 2, „Służba MO” 1963, nr 2 (35) 
Jura W., Z praktyki jednostek MO.: Zabójstwo prostytutki, „Służba MO” 1964, nr 1 (40)

Matysiak K., Przestępstwa eksploatacji prostytucji i jej sprawcy na terenie Trójmiasta, „Służba MO” $1969, \mathrm{nr} 3(72)$

AGP, 74x/4, Rozkaz nr 3/59 z dn. 6 II 1959 - Wytyczne ws. ścigania przestępstw nierządu karalnego, przeciwdziałania prostytucji oraz współudziału organów MO w zwalczaniu chorób wenerycznych

AGP, 4/59, Rozkaz Komendanta Głównego Milicji Obywatelskiej z dn. 23 I 1956 nr 2/56 w sprawie wzmożenia walki z prostytucją, k. 20-25

AGP, 4/113, Rozkaz KGMO nr 1/67 z dn. 10 II 1967 w sprawie milicyjnych izb dziecka

\section{Opracowania}

Barański P., Walka $z$ chorobami wenerycznymi w Polsce w latach 1948-1949, w: Kłopoty $z$ seksem w PRL, red. M. Kula, Warszawa 2012

Eisler J., Milicja Obywatelska w latach 1945-1989, w: Historia i rola społeczna formacji policyjnych w jubileuszu 85-lecia, red. G. Gryz; G. Jach, M. Laurentowska, Legionowo 2005, s. 97-115

Brzostek B., Za progiem. Codzienność w przestrzeni publicznej Warszawy lat 1950-1970, Warszawa 2007

Klich-Kluczewska B., Unzüchtiger Realsozialismus. Prostitution in der Volksrepublik Polen, „Osteuropa. Mythos Europa. Prostitution, Migration, Frauenhandel” 6, 2006, s. 303-317

Kochanowski J., Rewolucja międzypaździernikowa. Polska 1956-1957, Kraków 2017

Kosiński K., Historia pijaństwa w czasach PRL. Polityka - obyczaje - szara strefa - patologie, Warszawa 2008

Kosiński K., Prostytucja w PRL, „Polska 1944/45-1989” 9, 2009, s. 85-132

Kościańska A., Płeć, przyjemność i przemoc. Kształtowanie wiedzy eksperckiej o seksualności w Polsce, Warszawa 2014

Majer P., Milicja Obywatelska w systemie organów władzy PRL. Zarys problematyki i źródła, Toruń 2003

Ślęzak I., Refleksje nad zagadnieniem piętna $w$ relacjach badacza $i$ badanych na podstawie wywiadów z kobietami świadczącymi usługi seksualne, „Nauka i Szkolnictwo Wyższe” 2013, nr 1/41, s. $149-162$

Anna Dobrowolska - studentka piątego roku historii i socjologii na Uniwersytecie Warszawskim. Stypendystka ministra nauki i szkolnictwa wyższego. W 2017 r. otrzymała Diamentowy Grant na realizację projektu „Rewolucja czy ewolucja seksualna? Przemiany obyczajowości w Polsce w latach 1956-1989".

Kontakt: amdobrowolska@wp.pl 